\title{
Assessment of tree diversity in tropical moist deciduous forest of Mizoram University, Northeast India
}

\author{
Wapongnungsang \\ Department of Forest Science, School of Sciences, Nagaland University, Lumami- 798627, \\ India \\ Etsoshan Y Ovung \\ Department of Forestry, Mizoram University, School of Earth Science and Natural Resource \\ Management, Mizoram University, Tanhril-796004, India \\ SK Tripathi* \\ Department of Forestry, Mizoram University, School of Earth Science and Natural Resource \\ Management, Mizoram University, Tanhril-796004, India \\ *Corresponding author. Email: sk_tripathi@rediffmail.com
}

\section{Article Info}

https://doi.org/10.31018/

jans.v13i1.2436

Received: November 19, 2020

Revised: February 4, 2021

Accepted: February 9, 2021

\section{How to Cite}

Wapongnungsang et al. (2021). Assessment of tree diversity in tropical moist deciduous forest of Mizoram University, Northeast India. Journal of Applied and Natural Science, 13(1): 95 - 100. https://doi.org/10.31018/jans.v13i1.2436

\begin{abstract}
Forests are the main repository of biodiversity and play an important role in maintaining the ecological balance of nature. The status of species diversity reflects the health of the ecosystem. Therefore, the information on variation in the flora, for example, species composition, diversity and the basal area within any ecosystem like the forest of Mizoram University campus, Tanhril village, Aizawl would be important in understanding the forest wealth of the campus. Keeping in view, the study was analyzed the composition and diversity of Mizoram University campus by laying $16(10 \mathrm{~m} \times 10 \mathrm{~m})$ quadrats at random locations during 2015-2016. A total of 35 tree species belonging to 30 genera and 22 families were recorded in the forest communities of University Campus. Aporusa octandra was the most dominant tree species with maximum 31.50 importance value index (IVI), 3.29 Shannon diversity index $\left(\mathrm{H}^{0}\right)$ and 6972 Simpson's index (D) followed by Castanopsis tribuloides (28 IVI, $0.22 \mathrm{H}^{0}$ and $5256 \mathrm{D}$ ) and least dominant species recorded were: Albizia odoratissima, Anogeissus acuminate, Lithocarpus elegans, Oroxylum indicum. This study suggests that the forest patches are recovering after the establishment of the University because of adequate protection which was degraded in the past by the villager for collecting the trees for firewood, edible wild food and selecting the mature trees for felling. Therefore, further studies on regeneration potential of tree species would be crucial for the conservation of ecologically important species and to assess rates of their recovery following the disturbance.
\end{abstract}

Keywords: Euphorbiaceae, Lauraceae, Mizoram, Tree diversity, Tropical moist deciduous forest

\section{INTRODUCTION}

The degradation of forest is one of the most sensitive phenomena occurring over the World that profoundly affects the health of the natural ecosystems on which the livelihood of number of rural population depends. The factors responsible for the loss of species are many but the most important is the fragmentation of natural habitats (Lewis et al., 2015). The tropical forests are losing highest number of woody species every year as a result of habitat destruction due to the human activities (Hansen et al., 2013). In some Asian countries, forest loss (25\%) has been reported between 2010 and 2015 compared from 90's and thus it is important to crucially understand the human impact on forest in this region (Keenan et al., 2015).

In recent days, biodiversity assessment has put up a reputation due to its major impact on the practice of conservation (Naidu et al., 2018). In India, the northeast region includes a variety of flora and fauna and is one of the hotspots of biodiversity characterized by a significantly higher number of endemic species and the degree of threat to biodiversity (Tynsong and Tiwari, 2010). Further, information reported that these forest regions are characterized by high rainfall, humidity and favourable temperature. The previous studies reported that species diversity is based on the species richness and evenness (Ao et al., 2020), and the richness in- 
creasing from the pole to equator (Roy et al., 2004). Thus, the floristic composition of the vegetation changes gradually due to forest degradation and recovering during the course of succession (Singh et al., 2015).

Mizoram state considering as one of the seven sisters of northeast Indian occurs in the Indo-Burma biodiversity hotspot. According to India State of Forest report, 2015 , forest cover of Mizoram is $18,748 \mathrm{~km}^{2}$ which accounts for $88.93 \%$ of the total geographical area of the state $\left(21,081 \mathrm{~km}^{2}\right)$. Further, Mizoram has an area of $138 \mathrm{~km}^{2}$ Very Dense Forest (VDF), $5,858 \mathrm{~km}^{2}$ of Moderately Dense Forest (MDF) and an area of 12,752 $\mathrm{km}^{2}$ of Open Forest (OF). Mizoram is a hilly region where most tribal depend on forests for their livelihood such as agriculture, timber exploitation, fuelwood etc. (Tripathi et al., 2017) which are responsible for the degradation of the ecosystem. Studies reported that the changes in species diversity, fine root biomass, production and decomposition are strongly affected during ecosystem recovery following disturbance (Singh et al., 2015, Singha and Tripathi, 2017, Lalnunzira and Tripathi, 2018, Wapongnungsang et al., 2017; Wapongnungsang and Tripathi, 2018, Ao et al., 2020). Therefore, it is critical to understand the human impact to prioritize conservation of tropical forest and analyzing the cause of tropical forest deforestation and degradation is a prerequisite to manage these forests in a better way. Keeping in view, the information in the present study is an effort towards understanding the variation in the vegetation of flora with the major objective to determine species composition, diversity, basal area and canopy in Mizoram University campus, Tanhril village, Aizawl under the Mizoram University Campus

\section{MATERIALS AND METHODS}

\section{Area of the study site}

The Mizoram state encompasses the geographical coordinates of $21^{\circ} 56^{\prime}-24^{0} 31^{\prime} \mathrm{N}$ latitude and $92^{\circ} 16^{\prime}-93^{0} 26$
E longitude. The capital of the state is Aizawl. The average heights of the hills to the west of the state are about $1,000 \mathrm{~m}$ amsl. These gradually rise up to 1,300 $\mathrm{m}$ to the east. Some areas, however, have higher ranges which go up to a height of over 2,000 m.

Mizoram University was established on 2 July 2001, by the Mizoram University Act (2000) of the Parliament of India. This University campus is located in the Tanhril village (10-12 km) away from Aizawl city. The campus contains regenerating tropical wet evergreen and semievergreen forests, including a protected forested water catchment reserve in the north and a small biodiversity park. Several streams flow through the campus. Setlak Lui (Lui = river in Mizo) runs along the valley and is joined by Rultawi Lui, Hratdawng Lui, Lalmangkhawng Lui, and Lungsumzau Lui. Kel Lui and Chengkawl Lui also flow through the area. These streams mostly flow in a north-westerly direction to join the Tlawng River. The plants includes 384 species of vascular plants in 290 genera and 107 families. Common tree species include Aporusa octandra, Castanopsis tribuloides, Schima wallichii, Bischofia javanica, and Anogeissus acuminate, etc. Some bamboo species present include Melocanna baccifera, Dendrocalamus hamiltonii and Dendrocalamus longispathus (Lalchhuanawma, 2008).

The present study was conducted in the Mizoram University campus in Aizawl district of Mizoram, India. The climates are monsoonic with distinct seasons such as cold and dry (December-February), warm summer (March-June), humid monsoon (July-September) and cold monsoon (October-November). The temperature, humidity and rainfall data of the study sites during the sampling period (2015-16) are presented in Fig. 1

Tree species analysis was done randomly, placing 16 quadrats of $10 \mathrm{~m} \times 10 \mathrm{~m}$. Individual of tree species with $>10 \mathrm{~cm}$ girth at breast height $(\mathrm{BH})(1.37 \mathrm{~m}$ above ground) were recorded. The tree species were identified with the help of herbarium available in the Mizoram University (MZU) and in the Botanical Survey of India

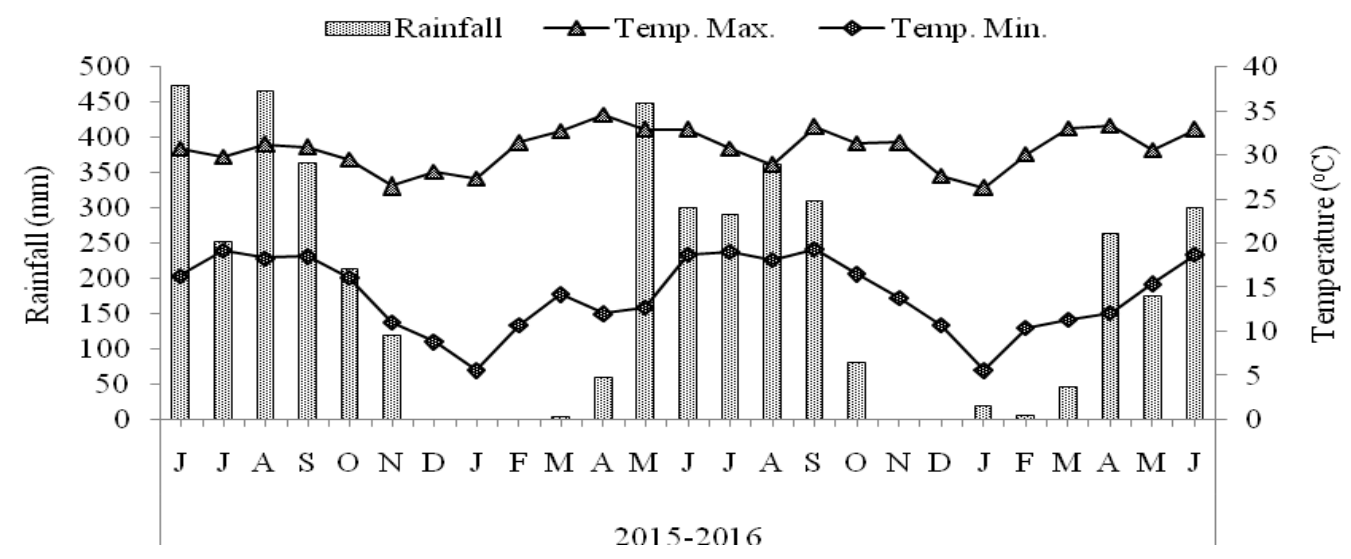

Fig. 1. Climatic representation of annual rainfall $(\mathrm{mm})$ and maximum and minimum temperature $\left({ }^{\circ} \mathrm{C}\right)$ of Mizoram University campus, Aizawl, Mizoram. 
(BSI), Shillong along the counter checked with referring regional floras (Haridasan and Rao, 1985; Sawmliana, 2013). The vegetation field data was analyzed for frequency, density and abundance (Curtis and Mclntosh, 1950). Importance value index (IVI) was determined as proposed by Phillips (1959). Diversity indices were determined by using Mishra (1968) and Mueller-Dombois and Ellenberg (1974).

\section{RESULTS AND DISCUSSION}

The present study recorded a total number of 35 tree species belonging to 30 genera and 22 families in Mizoram University campus (Table 1 ). The previous study by Devi et al. (2018) reported 125 tree species in the Reiek community reserve of Mamit district, Mizoram, which was considerably higher than the reports of the present study. The higher tree species diversity in the Reiek forest was due to the protection of forest for a long period of time (>100 years) and the judiciously managed by the villagers, whereas, the presently studied forest is recovering for the past 20 years following the disturbance after the development of the University. Before the establishment of the University area was degraded due to the overexploitation vegetation of the area which recovered following the establishment of the University. Recently, Ao et al. (2020) have reported 60 tree species belonging to 40 genra and 27 families in Fakim wildlife sanctuary, which was also higher than the present study because of adequate protection for a longer period. The number of tree species in the present study was less than the number of species reported by Sarkar and Devi (2014) in Hollongapar Gibbon Wildlife Sanctuary, Assam (75 tree species) and by Rasingam and Parthasarathy (2009) in Andaman Island (83 tree species) because of the young nature of the forest in the present study. The tree density was recorded 1644 individuals per hectare in the present study site. The studies by Devi et al. (2018) and Baishya et al. (2009) have reported 2145 individual/ha) in Reiek forest, Mizoram and 996 trees/ha in Nongkhyllem Wildlife Sanctuary in Meghalaya which was broadly comparable to the report of the present study. Total basal area $29.26 \mathrm{~m}^{2} \mathrm{ha}^{-1}$ in the present study area (Table 1) was also comparable with the report of the other studies in Meghalaya (Baishya et al. 2009) and in Hollongapar Gibbon Wildlife Sanctuary (Sarkar and Devi, 2014). The above finding revealed that the variation in tree density and basal area in the study site are because of differences in forest age topography and climatic factors, successional stages etc. (Swamy et al., 2000, Suthari, 2013).

Shannon-Weiner $\left(\mathrm{H}^{\prime}\right)$ index (3.29) of the present study site was within the range $(0.67-4.8)$ reported in the tropical forest of Indian sub-continent (Vishalakshi 1995, Panda et al., 2013). Simpson's index of dominance in the present study (Table 1 ) falls towards the lower side of the range (0.03-0.9) reported for Indian tropical forests (Deb and Sundriyal, 2011, Kushwaha and Nandy, 2012) which reflected high species diversity (0.97) of the forest. Pielou's Evenness index (0.92) indicates the equitable sharing of dominance among the individuals of the species in the present study which was similar $(0.81)$ to that of the value reported for Indian tropical evergreen forest of Meghalaya (Tynsong and Tiwari, 2011). This showed that the higher species evenness indicated more consistency in species distribution. Margalef's index indicates species richness (6.2) in the present study was towards to lower side of the range (4.5-23) reported for Indian tropical forests (Kumar et al., 2010, Sathish et al., 2013). The species evenness or equitability and species richness are proportional to species diversity and are among the important components affecting the diversity of forest ecosystem.

The IVI (32) of Aporusa octandra was highest, followed by Castanopsis tribuloides (28) in the present study site of Mizoram (Table 2). Least dominant tree species in terms of IVI were: Albizia odoratissima (3.27), Anogeissus acuminata (3.27), Lithocarpus elegans (3.27), Oroxylum indicum and each of these species had IVI of 3.27 (Table 2). The IVI value of tree species reflects the dominance of species in the population in a mixed forest community (Parthasarathy and Karthikeyan, 1997). Previous studies also revealed that IVI reflects the rich diversity of flora which provides food and shelter to large number of faunal diversity leading to higher community stability (MacArthur, 1955) resulting ecological balance in the environment in Tropical Moist forest of Mizoram ( Devi et al., 2018). On the other hand, anthropogenic activities such as the burning of forest, fuelwood and timber collection etc. could be the reason causing forest fragmentation which imposes a serious threat to the biodiversity. Families with the highest number of species richness were Euphorbiaceae (5) and Lauraceae (5) followed by Fabaceae (4) and Faga-

Table 1. Tree community structure of tropical moist forest of Mizoram University, Northeast India.

\begin{tabular}{ll}
\hline Parameters & Values \\
\hline No. of family & 22 \\
No. of genera & 30 \\
No. of species & 35 \\
Tree density (Individuals/ha) & 1644 \\
Tree basal area $\left(\mathrm{m}^{2} \mathrm{ha}^{-1}\right)$ & 29.26 \\
Shannon-Wiener diversity index & 3.29 \\
Simpson's index of dominance & 0.07 \\
Margalef's index & 6.2 \\
Pielou index (Evenness index) & 0.92 \\
\hline
\end{tabular}


ceae (4). The most abundant families in the study site were: Euphorbiaceae (525) followed by Fagaceae (456), Actinidiacea (269) and Rubiaceae (256) in Mizoram University campus (Table 2) (Pragasan and Parthasarath, 2010, Panda et al., 2013).

\section{Dominance diversity curve of Mizoram University Campus}

The dominance-diversity curve plotted based on IVI showed a normal species distribution (Fig. 2) indicating stable community in the present study. Normal species diversity curve in forest ecosystem indicates stable community as the available resources are shared among the various species present that showed a high probability that each species has better possibility to grow and reproduce. These results are similar to the previous report by Lynser and Tiwari (2015) under subtropical wet evergreen forest of Meghalaya and Devi at al. (2018) under the tropical moist forest of Reiek, Mizoram. Families with the highest species richness belonged to Euphorbiaceae followed by Moracea and Lauraceae (Table 2). Some recent studies showed that the dominant families were Dipterocarpaceae, Euphorbiaceae, Anacardiaceae and Meliaceae in the northeastern Ghats (Panda et al., 2013) and Mimosaceae, Euphorbiaceae, Rubiaceae and Anacardiaceae the in Tropical forests of South Eastern Ghats (Pragasan and Parthasarathy, 2010). Similarly, the present study showed the dominance of Euphorbiaceae and Moraceae in Mizoram University campus. Further, an epic decline in species sequence from 31 to 35 showed the least species dominance that reflects the effect of human disturbances on those species due to their utilization in many ways, e.g. fuelwood and domestic uses in the particular region (Fig. 2). This study suggests that the forest patches are recovering after the establishment of the University because of adequate protection which was degraded in the past by the villager for collection of excessive trees for firewood, edible wild food and felling of mature trees. The proper management plan for the conservation of species which are least abundant (e.g. Albizia odoratissima, Anogeissus acuminata, Lithocarpus elegans and Oroxylum indicum) in the area by preserving their seedlings for sustainable forest management in the future is suggested. Further, long-term monitoring of forests in the region would be better management and conservation forest in the future.

\section{Conclusion}

Findings of the present study revealed that Mizoram University campus owned by Mizo community harbours rich floral diversity with dominant species such as Aporusa octandra, Castanopsis tribuloides. Least species such as Albizia odoratissima, Anogeissus acu-

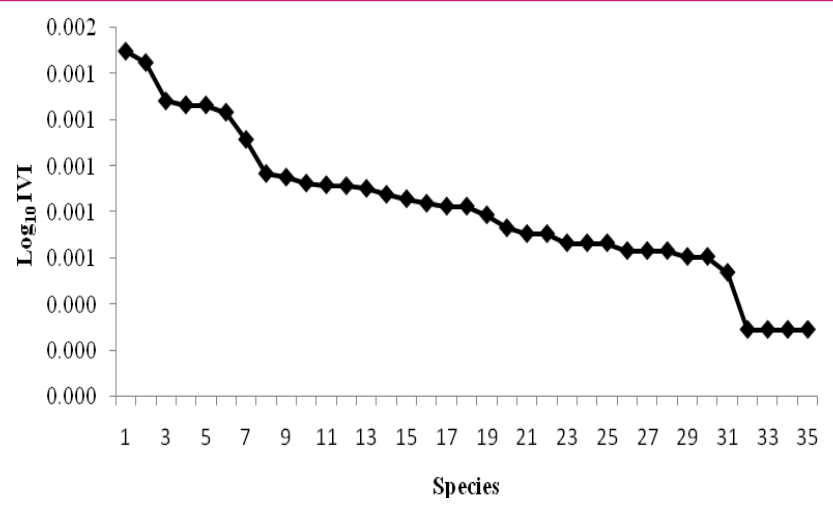

Fig 2. Dominance-diversity curves of tree species of Mizoram university campus in Tanhril village, Aizawl, Mizoram.

minata, Lithocarpus elegans and Oroxylum indicum suggests proper management plan for conservation of species and preservation of their seedlings for future sustainable forest management as the forest resources are important I to enhance carbon pool and climate change mitigation. Further, long-term monitoring of forests in the region is suggested for better forest management and conservation plans in the future.

\section{ACKNOWLEDGEMENTS}

The authors are thankful to M.Sc. students of 20152017 batch of the Department of Forestry, Mizoram University for their assistance in the field. Further, this author also thanks the Government of Mizoram for providing daily and monthly climatic data for the year 2015-2016.

\section{Conflict of interest}

The authors declare that they have no conflict of interest.

\section{REFERENCES}

1. Ao, A., Chnagkija, S. \& Tripathi, S. K. (2020). Species diversity, population structure, and regeneration status of trees in Fakim Wildlife Sanctuary, Nagaland, Northeast India. Biodiversitas, 21(6): 2777-2785.

2. Baishya, R., Barik, S. K. \& Upadhaya, K. (2009). Distribution pattern of aboveground biomass in natural and plantation forests of humid tropics in northeast India. Tropical Ecology, 50: 295-304.

3. Curtis, J. T. \& McIntosh, R. P. (1950). The interrelations of certain analytic and synthetic phytosociological characters. Ecology, 31: 434-455.

4. Deb, P. \& Sundriyal, R. C. (2011). Vegetation dynamics of an old-growth lowland tropical rainforest in North-east India: species composition and stand heterogeneity. International Journal of Biodiversity and Conservation, 3: 405430.

5. Devi, N. L., Singha, D. \& Tripathi, S. K. (2018)._Tree Species Composition and Diversity in Tropical Moist Forests of Mizoram, Northeast India. Indian Journal of Ecology, 45 
Wapongnungsang et al. / J. Appl. \& Nat. Sci. 13(1): 95 - 100 (2021)

Table 2. Physiological attributes of tree diversity in Mizoram University campus.

\begin{tabular}{|c|c|c|c|c|c|}
\hline Name of the species & Mizo name & Family & $\begin{array}{l}\text { Density } \\
\text { (no./ha) }\end{array}$ & $\begin{array}{l}\text { Basal area } \\
\left(\mathrm{m}^{2} \mathrm{ha}^{-1}\right)\end{array}$ & $\begin{array}{l}\text { IVI } \\
\text { value } \\
\end{array}$ \\
\hline Aganope thyrsiflora & Hulhu & Fabaceae & 50 & 0.38 & 10.22 \\
\hline Albizia chinensis & Vang & Leguminosae & 19 & 0.93 & 5.16 \\
\hline Albizia odoratissima & Thingri & Leguminosae & 6 & 0.70 & 3.27 \\
\hline Alseodaphne petiolarsis & Bul & Lauraceae & 19 & 0.74 & 5.16 \\
\hline Anogeissus acuminata & Zairum & Combretaceae & 6 & 1.12 & 3.27 \\
\hline Aporusa octandra & Chhawntual & Euphorbiaceae & 275 & 0.28 & 32.20 \\
\hline Archidendron monadelphum & Ardah & Mimosaceae & 31 & 0.65 & 7.06 \\
\hline Callicarpa arborea & Hnakiah & Verbenaceae & 50 & 1.43 & 9.67 \\
\hline Castanopsis tribuloides & Thingsia & Fagaceae & 219 & 0.86 & 26.94 \\
\hline Colona floribunda & Hnathap & Tiliaceae & 13 & 1.08 & 4.22 \\
\hline Desmodium triangulare & Sebehliang & Fabaceae & 19 & 0.37 & 5.16 \\
\hline Elaeocarpus aristatus & Theikelek & Elaeocarpaceae & 50 & 0.55 & 9.91 \\
\hline Emblica officinalis & Sunhlu & Euphorbiaceae & 19 & 0.96 & 5.16 \\
\hline Engelhardtia spicata & Hnum & Juglandaceae & 31 & 0.44 & 7.06 \\
\hline Erythrina stricta & Fartuah & Fabaceae & 31 & 1.85 & 7.06 \\
\hline Eurya cerasifolia & Sihneh & Pentaphylacaceae & 75 & 0.82 & 12.51 \\
\hline Ficus hirta & Sazutheipui & Moraceae & 13 & 0.57 & 4.22 \\
\hline Ficus racemose & Theichek & Moraceae & 13 & 0.41 & 4.22 \\
\hline Glochidion khascium & Thingpawnchhia & Euphorbiaceae & 31 & 0.80 & 7.06 \\
\hline Ilex umbellulate & Thinguihahni & Aquifoliaceae & 12 & 0.50 & 4.22 \\
\hline Lepionurus sylvestris & Anpangthuam & Olacaceae & 6 & 0.25 & 3.27 \\
\hline Lithocarpus elegans & Thingpuithing & Fagaceae & 6 & 0.32 & 3.27 \\
\hline Lithocarpus xylocarpa & Then & Fagaceae & 19 & 0.54 & 5.16 \\
\hline Litsea lancifolia & Hnapawhte & Lauraceae & 19 & 0.45 & 5.75 \\
\hline Litsea monopetala & Nauthak & Lauraceae & 44 & 2.55 & 8.75 \\
\hline Macaranga indica & Hnakhar & Euphorbiaceae & 75 & 0.73 & 12.77 \\
\hline Morus macroura & Lungli & Moraceae & 6 & 0.27 & 3.27 \\
\hline Oroxylum indicum & Archangkawm & Bignoniaceae & 6 & 0.47 & 3.27 \\
\hline Saurauia punduna & Tiar & Actinidiaceae & 144 & 0.79 & 19.84 \\
\hline Schima wallichi & Khiang & Theaceae & 100 & 1.56 & 16.32 \\
\hline Sterculia villosa & Khaupui & Malvaceae & 19 & 2.81 & 5.16 \\
\hline Syzygium cumini & Lenhmui & Myrtaceae & 44 & 0.66 & 8.78 \\
\hline Syzygium grandis & Theichawl & Myrtaceae & 44 & 1.34 & 8.96 \\
\hline Tabernaemontana divaricata & Par arsi & Apocynaceae & 19 & 0.50 & 5.16 \\
\hline \multirow[t]{2}{*}{ Wendlandia grandis } & Batling & Rubiaceae & 113 & 0.58 & 16.61 \\
\hline & & & 1644 & 29.26 & 300.00 \\
\hline
\end{tabular}


(3): 454-461.

6. Hansen, M. C., Potapov, P. V., Moore, R., Hancher, M., Turubanova, S. A., Tyukavina, A., Thau, D., Stehman, S. V., Goetz, S. J. \& Townshend, J. R. G. (2013). Highresolution global maps of 21st-century forest cover change. Science, 342: 851-853.

7. Haridasan, K. \& Rao, P. R. (1985). Forest Flora of Meghalaya. Vol. 1 and 2. Bishen Singh Mahendra Pal Singh, Dehra Dun.

8. Keenan, R., Reams, G., Achard, F., Freitas, J., Grainger, A. \& Lindquist, E. (2015). Dynamics of global forest area: results from the FAO Global Forest Resources Assessment 2015. Forest Ecology and Management, 352: 9-20.

9. Kumar, J. I. N., Kumar, R. N., Bhoi, R. K. \& Sajish, P. R. (2010). Tree species diversity and soil nutrient status in three sites of tropical dry deciduous forest of western India. Tropical Ecology, 51: 273-279.

10. Kushwaha, S. P. S. \& Nandy, S. (2012). Species diversity and community structure in sal (Shorea robusta) forests of two different rainfall regimes in West Bengal, India. Biodiversity and Conservation, 21, 1215-1228.

11. Lalnunzira, C. \& Tripathi, S. K. (2018). Leaf and root production, decomposition and fluxes of carbon and nitrogen during stand development in tropical moist forests, northeast India. Soil Research, 56, 306-317.

12. Lalchhuanawma, (2008). Ecological studies on plant diversity and productivity of herbaceous species in Mizoram university campus at Tanhril, Aizawl, Mizoram (N.E. India). PhD Thesis, Mizoram University, Aizawl.

13. Lewis, S. L., Edwards, D. P., Galbraith, D. (2015). Increasing human dominance of tropical forests. Science, 349, 827-832.

14. Lynser, M. B. \& Tiwari, B. K. (2015). Tree Diversity, Population Structure and Utilization in Traditionally Managed Sub-Tropical Wet Evergreen Forests of Meghalaya, North East India. International Research Journal of Environment Sciences, 4, 1-5.

15. Macarthur, R. H. (1955). Fluctuation of animal population, and a measure of community stability. Ecology, 36, 533536.

16. Mishra, R. (1968). Ecology Work Book. Oxford and IBM publishing Co. Calcutta, 244.

17. Muller-Dombios, D. J. \& Ellenberg, H. (1974). Aims and Methods in Vegetation Ecology. John Wiley and Sons, New York.

18. Naidu, M. T., Premavani, D., Suthari, S. \& Venkaiah, M. (2018). Assessment of tree diversity in tropical deciduous forests of North-central Eastern Ghats, India, Geology Ecology and Landscape, 2, 216-227.

19. Panda, P. C., Mahapatra, A. K., Acharya, P. K. \& Debata, A. K. (2013). Plant diversity in tropical deciduous forests of Eastern Ghats, India: A landscape level assessment. International Journal of Biodiversity Conservation, 5: 625-639.

20. Parthasarathy, N. \& Karthikeyan, R. (1997). Plant biodiversity inventory and conservation of two tropical dry evergreen forests on the Coromandel Coast, south India. Biodiversity and Conservation, 6,1063-1083.

21. Phillips, E. A. (1959). Methods of Vegetation Study. Henery Holt and Co., Inc.

22. Pragasan, L. A. \& Parthasarathy, N. (2010). Landscapelevel tree diversity assessment in tropical forests of southern Eastern Ghats, India. Flora - Morphol, Distri, Funct.
Ecology of Plant, 205, 728-737

23. Rasingam, L. \& Parthasarathy N. (2009). Tree species diversity and population structure across major forest formations and disturbance categories in Little Andaman Island, India. Tropical Ecology, 50, 89-102.

24. Roy, A., S. K. Tripathi \& Basu, S.K. (2004). Formulating diversity vector for ecosystem comparison. Ecology Model, 179(4), 499-513.

25. Sarkar, M. \& Devi, A. (2014). Assessment of diversity, population structure and regeneration status of tree species in Hollongapar Gibbon Wildlife Sanctuary, Assam, Northeast India. Tropical Plant Research, 1, 26-36.

26. Sathish, B. N., Viswanath, S., Kushalappa, C. G., Jagadish, M. R. \& Ganeshaiah, K. N. (2013). Comparative assessment of floristic structure, diversity and regeneration status of tropical rain forests of Western Ghats of Karnataka, India. Journal of Applied \& Natural Science, 5, 157 $-164$.

27. Sawmliana, M. (2013). The book of Mizoram plants. Published by P. Zakhuma, Aizawl, Mizoram.

28. Singh, Sh. B., Mishra, B. P. \& Tripathi, S. K. (2015). Recovery of plant diversity and soil nutrients during stand development in subtropical forests of Mizoram. Northeast India. Biodiversitas, 16 (2), 205-212.

29. Singha, D. \& Tripathi, S. K. (2017). Variations in fine root growth during age chronosequence of moist tropical forest following shifting cultivation in Mizoram, northeast India. Tropical Ecology, 58, 1- 11.

30. Suthari, S. (2013). Biodiversity characterization and aboveground vegetation carbon pool assessment in Northern Telangana at landscape level using geospatial technique (Ph.D. Thesis). Department of Botany, Kakatiya University, Warangal.

31. Swamy, P. S., Sundarapandian, S. M., Chandrasekar, P. \& Chandrasekaran, S. (2000). Plant species diversity and tree population structure of a humid tropical forest in Tamil Nadu, India. Biodiversity and Conservation, 9, 1643-1669.

32. Tripathi, S. K., Vanlalfakawma, D. C. \& Lalnunmawia, F. (2017). Shifting cultivation on steep slopes of Mizoram, India: Impact of policy reforms. In: Cairns M. (Ed.) Shifting Cultivation Policies: Balancing Environmental and Social Sustainability, CABI Publishing, London, pp. 1076.

33. Tynsong, H. \& Tiwari, B. K. (2010). Diversity of plant species in are canutagro forest of south Meghalaya, northeast India. Journal Forest Research, 21, 281-286.

34. Tynsong, H. \& Tiwari, B. K. (2011). Diversity and population characteristics of woody species in natural forests and arecanut agro-forests of south Meghalaya, northeast India. Tropical Ecology, 52, 243-252.

35. Vishalakshi, N. (1995). Vegetation analysis of two tropical dry evergreen forests in southern India. Tropical Ecology, $36,117-127$.

36. Wapongnungsang, Hauchhum, R. \& Tripathi, S. K. (2017). Litter Decomposition Vis-a-Vis Carbon and Nitrogen Dynamics of Tephrosia candida Components in Different Fallow Periods Following Shifting Cultivation in Mizoram. Indian Journal of Ecology, 44(4), 791-796.

37. Wapongnungsang \& Tripathi, S. K. (2018). Fine root growth and soil nutrient dynamics during shifting cultivation in tropical semi-evergreen forests of northeast India. Journal of Environmental Biology, 40, 45-52. 